\title{
POTENTIAL MICROBIAL CONTAMINATION ON KEBAB MEAT IN THE AREA OF UNIVERSITY OF MUHAMMADIYAH MALANG
}

\author{
Bayu Etti Tri Adiyastiti ${ }^{1}$, Rio Lingga ${ }^{2)}$, Syaiful Arifin ${ }^{2)}$ Listiari Hendraningsih ${ }^{1)}$ \\ 1) Lecturer of Animal Husbandry Department, Fakultas Pertanian-Peternakan, Universitas Muhamadiyah Malang \\ Jl. Raya Tlogomas No.246 Malang, Jawa Timur 65144, Indonesia \\ ${ }^{2)}$ Graduate student of Animal Husbandry Department, Fakultas Pertanian-Peternakan, Universitas \\ Muhamadiyah Malang Jl. Raya Tlogomas No.246 Malang, Jawa Timur 65144, Indonesia \\ E-mail: bayuetti@umm.ac.id,
}

Accepted 16 April 2019; Revised 11 September 2019

Published 17 Oktober 2019

\begin{abstract}
The aim of this research was to find the safety level of consuming kebab meat in the University of Muhammadiyah Malang campus area in terms of the number of microbial total plate count, Salmonella, E. coli, and S. aureus. The research was conducted with 2 treatments and 2 replications. The first observation was done during the outlet opening time and the second observation was around 8 hours after or when the outlet was going to be closed. Each treatment was sampled at 4 kebab outlets with different brands in the UMM area, so the total was 16 samples for laboratory analysis. The sample is directly pack in sterile bag, labeled sample code and bring them to the laboratory. The sample was taken to microbiology analysis in laboratory. The result showed the number of bacteria of 2 outlets with contamination levels exceeding the maximum limit set by Indonesia National Standards (SNI). The highest total bacteria count is owned by $4^{\text {th }}$ outlet which is $2.2 \times 10^{5} \pm 0.85 \times 10^{5} \mathrm{CFU} / \mathrm{g}$ (daytime) and 44 . $3 \times 10^{5} \pm 2$. $97 \times 10^{5} \mathrm{CFU} / \mathrm{g}$ (night). The lowest Total bacteria is owned by $1^{\text {st }}$ outlet, neither daytime nor evening bacterial colonies are found. Identification Salmonella, E. coli, and Staphylococcus aureus for all outlets are negative. The conclusion of this study is that two of the four kebab outlets in the UMM area was detected the bacteria total counts above of the contamination limit set by SNI 7388: 2009 and all of kebab's meat were negative identified or did not contain E. coli, Staphylococcus aureus, and Salmonella.
\end{abstract}

Keywords: Kebab; pathogen bacteria; microbiology 


\section{INTRODUCTION}

A famous Middle Eastern meat dish in Indonesia is kebab. Food processing from the Middle East is almost the same as processed food in Indonesia, which is rich in herbs and spices, so it suits the tastes of Indonesian people, not only the herbs but also raw materials for halal Middle Eastern cuisine are also the reason why dishes from the Middle East are in great demand in Indonesia. Indonesia is a country with a majority Muslim population. In general, kebab meat is made from lamb, goat, and beef or poultry meat. Kebab is a typical Turkish food. According to a survey conducted by Gwyneth (2009), some people think that kebabs are made from lamb, beef, goat and chicken meat, but some also think kebabs should only come from mutton and lamb. Etymologically kebab comes from Arabic that is kebab which means fried meat, not grilled or grilled meat.

Kebab in Persian is tabahajah which means a dish of fried meat. In some Turkish literature, the term kebab is used for dishes in the form of meatballs made from chicken or minced lamb (Lversluys, 2015). A popular kebab in Indonesia is a type of kebab from Turkey, namely Kebab Doner in the form of grilled meat which is hung vertically and then sliced, served rolled with vegetables with pita bread or tortilla bread. In Indonesia, kebabs are easy to find as street foods now. Kebabs sold using carts alongside the road are often poorly maintained. The kebab's meat was left exposed to the outside air. Meat is medium that is easily contaminated as it has high nutritional content, such as fat, protein, water makes it easy for microbes to grow and develop. Meat contaminated with microbes exceeds the threshold if consumed by somebody will cause health problems.

The campus area is a strategic location for business. According to Wulandari and Zubaidah (2016), the distribution of meatball kebab products is directly at the place where consumers are. Meatball kebabs are fast food, so the production process is also done at the point of sale according to consumer orders. Outlets are designed as attractive as possible and will be placed close to students and employees such as universities, schools, boardinghouse areas, and offices. This is utilized by food sellers, including kebab's sellers who open outlets around the University of Muhammadiyah Malang (UMM), which are the student as target markets. Kebab outlets located in the UMM area are scattered in several locations on the side of the highway and stored the meat for a long time so that the potential for microbial growth.

Microbes contaminants such as Salmonella sp., E. coli, and Staphylococcus sp. The results of the study of Kayisoglu et al. (2002) microbiological analysis on a sample of raw uncooked kebab doner showed 5.68 to $4.92 \mathrm{CFU} / \mathrm{g}$ ALT; 5,14$3,488 \mathrm{CFU} / \mathrm{g}$ of psychotropic bacteria; 4.79$2.88 \mathrm{CFU} / \mathrm{g}$ coliform and 4.96-3.55 CFU/g mushroom and mold. All kebab samples were thought to contain Salmonella Sp, both in cooked chicken kebabs $(80 \%$ of the sample) and in the beef kebabs (40\% of the

How to cite:

Adiyastiti, B. E. T., Lingga, R., Arifin, S., \& Hendraningsih, L. (2019). Potential Microbial Contamination on Kebab Meat in the Area of University of Muhammadiyah Malang. Jurnal Ilmu dan Teknologi Hasil Ternak, 14 (2), 107-116 
sample) which were cooked undercooked. $40 \%$ of the total sample contained $C$. perifringens. Consumers, especially students, need to maintain their health. They have to care about the cleanliness of the food consumed. Therefore, it is necessary to conduct research on the potential of microbial contamination in kebab meat that is scattered around the campus area.

The purpose of this study was to determine the safety of kebab meat consumption in the area of the University of Muhammadiyah Malang in terms of the number of microbial Total Plate Count, Salmonella, E. coli, and S. aureus. The benefit of this research can provide information related to food safety, especially kebab meat and about the potential for microbial contamination in kebab meat.

\section{MATERIALS AND METHODS}

The research used samples from 4 kebab outlets located in the area of the University of Muhammadiyah Malang (UMM), starting with a location survey, sampling kebab's meat for analysis. Analysis of the microbial contamination in the Laboratory of Biomedics, Faculty of Medicine, University of Muhammadiyah Malang

The research method was surveyed by kebab outlets around the UMM area. The selection of outlets using the purposive sampling methods which is the outlet closest to UMM. The results were carried out statistically by descriptive analysis. The research was conducted with 2 treatments and 2 replications each time. Each treatment was sampled at 4 kebab outlets with different brands in the UMM area, a total of 16 samples were observed for laboratory analysis. The tools used were tweezers, scissors, knives, sterile plastic, beaker glass, Erlenmeyer flask, test tubes, inoculating loop, petri dishes, pipettes, Bunsen Burner, Quebec colony counters, cooler boxes, and electric scales.

The material used was kebab meat from kebab outlets in the UMM campus area. The media used are Buffer Pepton Water (BPW) $0.1 \%$, Plate Count Agar (PCA), Escherichia coli broth (ECB), Salmonella Shigella Agar (SSA) media, Nutrient Agar (NA), and other ingredients according to work procedures. The study was conducted in the following stages:

\section{Sampling}

Samples in the form of kebab meat amounted to 16 samples purchased from 4 different outlets located in the UMM area. Sampling was carried out at 2 times, the first when the outlet was open and the second was around 8 hours after the outlet was open or when the outlet was closed. Samples that have been purchased directly stored in a sterile plastic, labeled sample code and put in a box containing ice (cool box) and taken to the laboratory.

\section{Qualitative and quantitative microbial analysis}

Samples were analyzed by microbial methods based on the method of SNI (Indonesian National Standard) 2897-2008 on trial microbial contamination methods in meat, eggs, and milk, as well as processed products.

TPC calculation is done by pour plate method by adding $25 \mathrm{~g}$ of the sample with $0.1 \%$ peptone water buffer and then mixed until homogenous. The meat samples were then crushed are then diluted as much as $10^{-1}$ (D1). A total of $1 \mathrm{~mL}$ of suspension from $\mathrm{P} 1$ was transferred with a sterile pipette into $9 \mathrm{~mL}$ of BPW $0.1 \%$ sterile to obtain a 
$10^{-2}$ dilution (D2). Dilutions are carried out $10^{-3}, 10^{-4}, 10^{-5}$ and so on in the same way. Furthermore, the number of colonies is calculated using a colony counter containing 25-250 colonies. E. coli analysis by using the MPN method, the initial stage is to dilute the sample until a $10^{-3}$ dilution, it taken $1 \mathrm{~mL}$ from each dilution into 3 series of LSTB tubes containing Durham cylinders. The sample was incubated at $35^{\circ} \mathrm{C}$ for $24-48 \mathrm{~h}$. The next step is to observe the presence of gas in the Durham cylinder, if it contain the gas indicates a positive result. the positive results will proceed to the confirmation test (confirmation). Salmonella sp test was carried out using the pour plate method with Salmonella sigella agar (SSA) media suspension then poured into selective salmonella shigella agar (SSA) media. The incubation of the culture with the position of the lid of the petri dish remained above, then the cup was reversed. After being incubated at $37^{\circ} \mathrm{C}$ for $24 \mathrm{~h}$, a red dot black colony is found in the center.

\section{RESULT AND DISCUSSION}

Determining food quality and food safety analyzing are needed. One of them is microbiology analysis. According to Fardiaz (1993) that "Microbiological analyzing is one of the important tests, because in addition to helping the resistance of food, it can also be used as a food safety indicators. There are various kinds of microbial methods such as test of quantitative, qualitative and indicator bacterial tests. Quantitative tests improve the quality and durability of food, qualitative tests determine the level of food safety and testing of indicator bacteria determine the level of food welfare. Each food has different test depending on various factors, it likes the way of handling, storing, packaging, food typing, food composing and other factors. Improper of food handling and processing can cause contamination by pathogenic bacteria which are making them growth multiply during storage, so produce toxins that can be harm for humans. Food poisoning by bacteria in human body make the body infection. Intoxication is caused by bacterial toxins that form in food when bacteria growth multiply, whereas food poisoning contains infections, related to the entry of bacteria into the body through contaminated food and the body reacts to these bacteria (Badan Pengawas Obat dan Makanan, 2008).

The ingredients for making kebabs are meat that it is very potential for contamination by microbes moreover the outlets are standing on the side of the road. Food ingredients from livestock (meat, eggs, milk) and processed products are perishable, easily damaged and an excellent medium for microbial growth. Meat is a good food material for microbial growth because: 1) has a high water content $(68,75 \%), 2)$ rich in nitrogenous substances, 3) rich in minerals for microbial growth, and 4) contain microbes that are beneficial for other microbes (Betty and Yendri, 2007). Microbial contamination in foods of animal product that can harm human health are Coliform, E. coli, Enterococci, S. aureus, Clostridium sp., $\quad$ Salmonella $s p$. , Champhylobacter sp., and Listeria sp. (Syukur, 2006). The results of the laboratory analysis of the number of bacteria, Escherichia coli, S. aureus and Salmonella $s p$ kebab meat are presented in Table 2 .

\section{Total Bacteria}

Determination of the total number of bacteria carried out by Total Plate count (TPC) method. Generally,the result indicated 2 of the 4 outlets have exceeded 
the limit of contamination of processed meat by smoking. SNI (2009) determines the maximum limit of microbial contamination in food is $1 \times 10^{5} \mathrm{CFU} / \mathrm{g}$. Sampling in this research is on the daytime when the kebab outlet starts to open and the second is on the evening before the outlet closed. TPC results for daytime treatment obtained 3 of 4 kebab outlets were found no microbial colonies on jelly nutrient media. In the calculation of the number of bacteria only outlet 4 obtained above the specified contamination limit, the results of the calculation of outlet 4 is $2.2 \times$ $10^{5} \pm 0.85 \times 10^{5} \mathrm{CFU} / \mathrm{g}$. Night time sampling results obtained 2 of 4 outlets exceeding the maximum limit, they are outlet 2 and outlet 4 . The total number bacteria of outlet 2 is $1.85 \times 10^{5} \pm 0.64 \times$ $10^{5} \mathrm{CFU} / \mathrm{g}$ and outlet 4 is $4.3 \times 10^{5} \pm 2.97 \times$
$10^{5} \mathrm{CFU} / \mathrm{g}$. Research result of Lasmini and Sitorus (2017) showed the calculation of the Total Plate count for 5 kebab meat samples sold in Jalan Durian Pekanbaru, only 1 sample fulfilled the requirements and 4 samples had a TPC value exceeding the maximum limit of microbial contamination in meat which is more than $1 \times 10^{5} \mathrm{CFU} / \mathrm{g}$, as well as research conducted by Choiriyah $e t$ al. (2016) showed that the total microbial test was only 1 sample of kebab meat from 40 kebab meat samples that met the standard total microbial count requirements. The result above of limit contamination because kebab material is meat which is indeed perishable and easy for bacterial growth. Furthermore, it does not support good meat storage. The kebab outlets located in the open space and in the side road position.

Table 1. Microbial Trial Methods

\begin{tabular}{lll}
\hline Variable & unit & \multicolumn{1}{c}{ Methods } \\
\hline Total Plate Count & CFU/g & Total Plate Count (TPC) \\
Escherichia coli & MPN/g & MPN (Most Probable Number) \\
Staphylococcus aureus & CFU/g & Coagulate Trial \\
Salmonella $s p$. & CFU/g & Salmonella enrichment \\
\hline
\end{tabular}

Tabel 2. The Total amount of Bacteria, Escherichia coli, Staphylococcus aureus and Salmonella sp kebab meat in UMM areas

\begin{tabular}{lcccc}
\hline \multirow{2}{*}{ Parameters } & \multicolumn{5}{c}{ Outlet } \\
\cline { 2 - 5 } $\begin{array}{l}\text { Total Bacteria } \\
\text { (CFU/g) }\end{array}$ & & 2 & 3 & 4 \\
Daytime & 0 & 0 & & \\
Evening & 0 & $1.85 \times 10^{5} \pm 0.64 \times 10^{5}$ & $0.04 \times 10^{5} \pm 0.02 \times 10^{5}$ & $4.3 \times 10^{5} \pm 0.85 \times 10^{5} \pm 2.97 \times 10^{5}$ \\
\hline Escherichia coli & & & & \\
Daytime & Negative & Negative & Negative & Negative \\
Evening & Negative & Negative & Negative & Negative \\
\hline $\begin{array}{l}\text { Staphylococcus } \\
\text { aureus }\end{array}$ & & & & \\
Daytime & Negative & Negative & Negative & Negative \\
Evening & Negative & Negative & Negative & Negative \\
\hline $\begin{array}{l}\text { Salmonella } s p \\
\text { Daytime }\end{array}$ & Negative & Negative & Negative & Negative \\
Evening & Negative & Negative & Negative & Negative \\
\hline
\end{tabular}




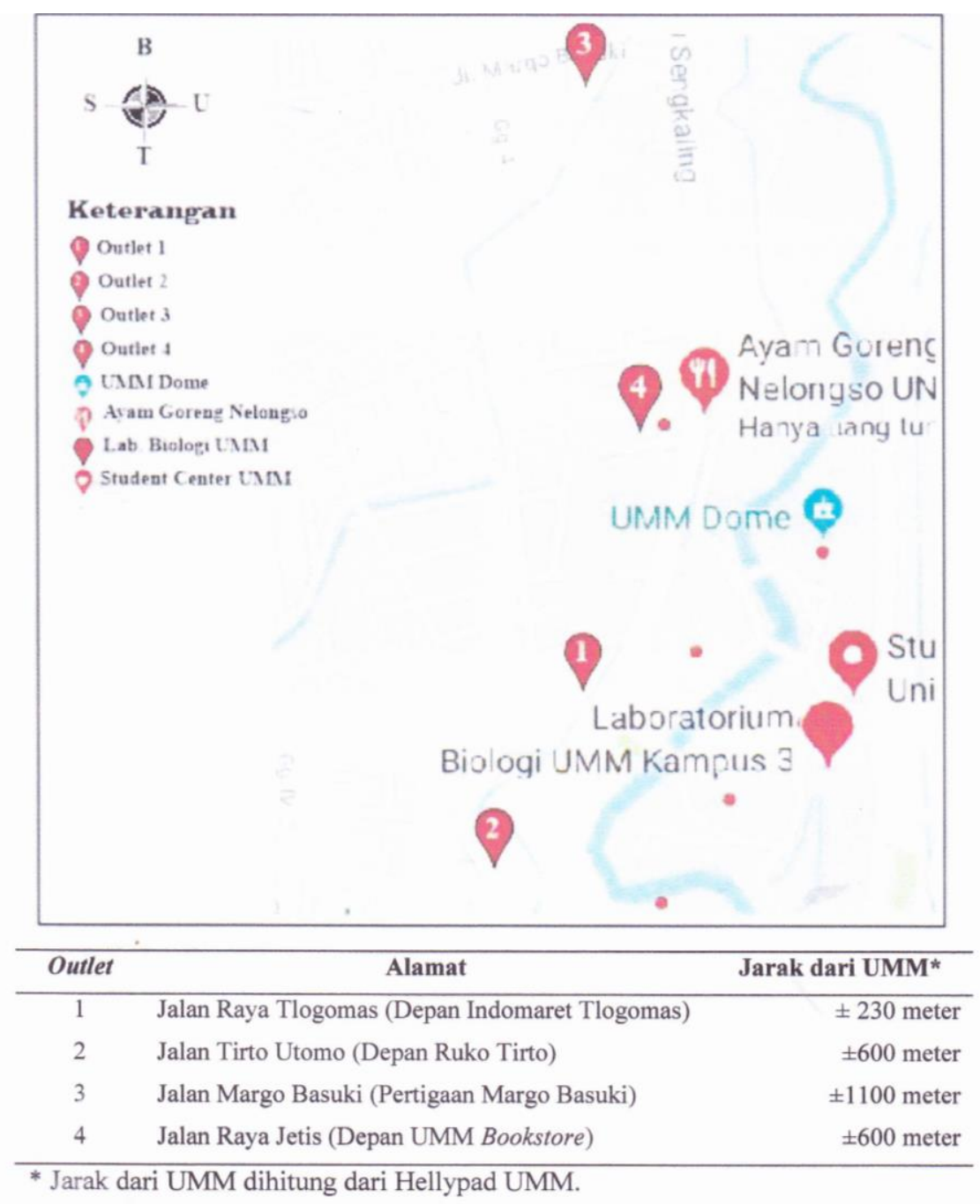

Figure 1. Site plan kebab outlets

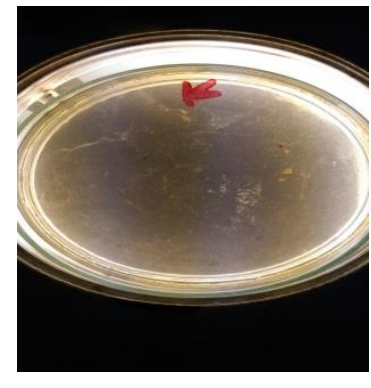

A

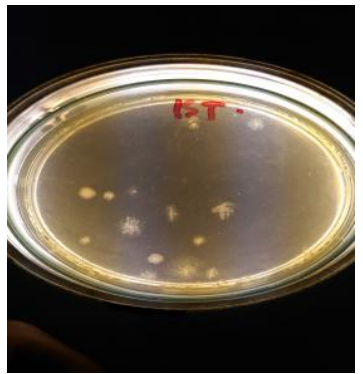

B

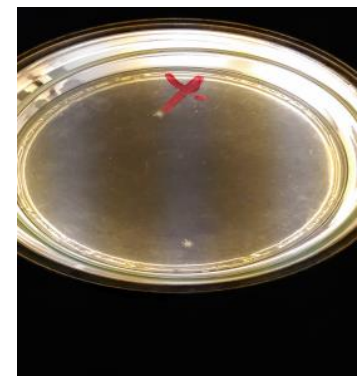

C

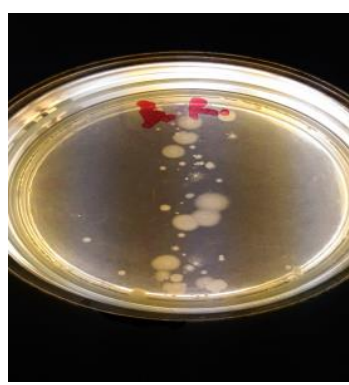

D

Figure 2. Identification of Bacterial
Description: A. Outlet 1
B. Outlet 2
C. Outlet 3
D. Outlet 4

The kebab seller does not make the toaster stay on fire or closed the grilling lid for storing the kebab's meat. The presence of bacteria indicates the level of food hygiene.
Cookware and utensils used in the supply of food can also be a source of contamination, for example knives used to cut raw materials, such as raw meat can be contaminated with 
pathogens. If the equipment is used again without being cleaned properly, especially if it is used for food that is already cooked or ready to eat, the pathogen can move and pose a serious threat to food (Adam and Motoarjemi, 2013). Bacteria found in the TPC indicate the bacillus genus. Bacillus is a genus of gram-positive rod-shaped bacteria (bacilli) and members of the phylum Firmicutes. Bacillus species can be obligate aerobes (ability to oxygen), or optional anaerobes (have the ability to be aerobic or anaerobic. Bacillus provides freeliving species (non-parasitic) and parasitic pathogens.

In addition, the highest total bacterial was owned by outlet 4 , it is $2.2 \times 10^{5} \pm$ $0.85 \times 10^{5} \mathrm{CFU} / \mathrm{g}$ (daytime) and $44.3 \times$ $10^{5} \pm 2.97 \times 10^{5} \mathrm{CFU} / \mathrm{g}$ (evening time). The lowest total bacteria owned by outlet 1 , both during the day and at evening, there were no bacterial colonies. Outlet 4 results both during the day and at evening obtained above the maximum limit of contamination. This is happened because outlet 4 have kebab's meat not optimal in meat processing from the starting point. This can be seen from the color of the meat which is still bright red. Outlet 4 has the brightest flesh color compared to other outlets. Raw material treatment is important to maintain product quality. Raw materials for meat that are still bright red. It shown the meat still be under cooked and storing is not done properly. The number of bacteria at night at outlet 4 is increasing, it because the bacteria in the meat are growing multiply. The development of these bacteria is supported by an outlet located on the edge of the highway, so that it will be easily contaminated by the environment. This is almost the same as what happened with outlet 2 , the results of the bacterial count are changes from daytime to evening, it is assumed due to improper storage, the seller leaves the meat for too long in contact with the surrounding air. According to Choiriyah et al. (2016) bacterial contamination factors make influence the total number of microbial on kebab meat showed $82.5 \%$ of kebab sellers with less cooking quality, $17.5 \%$ of kebab sellers with less personal hygiene quality, seller with lack equipment hygiene at $22.5 \%$, sellers with lack transportation quality at $45 \%$, sellers with lack storage conditions at $50 \%$, and lack environmental sanitation conditions by $20 \%$. Sugiyoto (2015) also observed total bacterial (TPC) in meat samples and stated 3 meat samples. One Sampling was at the Tugu Market and 2 meat sampling were at the Halim Way Market with the total number of microbial above the standard, meat contaminated with the number of bacteria above the presumed standard because the place of selling is less clean and mixed with other outlets who are not the same type. This indicate that environment is very influential on the growth microbes in meat and meat process seller.

\section{E. coli, S. aureus and Salmonella sp}

The results of identification of $E$. coli, $S$. aureus and Salmonella $s p$ in this kebab meat study were negative for all outlets. Kebab meat samples do not contain harmful bacteria, pathogenic bacteria. Biological hazards (microbial) in food need attention because this type of hazard is often the causative agent of food poisoning. E. coli is a pathogenic bacteria that often causes food poisoning and it is also one of the microbial indicators of sanitation, while $S$. aureus is a bacterium that usually inhabits the nose, mouth, throat, and skin. The presence of Escherichia coli in food can indicate lack environmental sanitation practices while the presence of $S$. aureus identifies lack 
hygiene practices (Badan Pengawas Obat dan Makanan, 2008). In general, kebab's meat used meat from good livestock and good handling before and after slaughter.

The kebab's meat studied did not have E. coli because it did not contain E. coli bacteria. E. coli bacteria died during the process of heating or roasting kebab's meat, the materials and equipment used were clean and good sanitation of the sellers of each outlets. The process of grilling kebab meat is done for more than 1 hour so this can help kill E.coli. Research conducted by Novianti (2015) shows that the food of skewed meatballs did not have E. coli bacteria, possibly because the bacteria died during the heating process or the production of skewed meatballs and the water used were clean water. The maximum limit of $E$. coli microbial contamination in food is $<3$ / g (SNI, 2009).

$S$. aureus is a bacterium that circulates everywhere, such as air, dust, water, milk, food, tableware, the environment and the human or animal body found in the skin, hair/fur and respiratory tract. Humans and animals are the main sources of infection (Chotiah, 2009). The observation results for the presence of $S$. aureus found the presence of yellow bacterial colonies on Mannitol Salt Agar (MSA) media marked by the appearance of MSA media color change from red to yellow or the appearance of yellow colonies. The yellow color arises because of the fermentation of mannitol by S. aureus. S. aureus colonies in the cup appear golden yellow, round, and convex (Odunayo et al., 2011). This study did not find any yellow color in the petri dish so the results were negative which meant no identification of $S$. aureus. S. aureus is one of the pathogenic bacteria and can be used as an indicator of unhygienic food processing, it can produce enterotoxins that can be directly detected in food. This kebab sample at 4 outlets was stated negative or no $S$. aureus was found so that it could be suspected as a hygienic outlet. The maximum limit of microbial contamination of $S$. aureus in food is $1 \times 10^{2}$ colonies / $\mathrm{g}$ (SNI, 2009). This is supported by the research of Lasmini and Sitorus (2017) that in all kebab meat samples taken from kebab sellers on Jalan Durian Pekanbaru no $S$. aureus was found. Salmonella $s p$ is a bacterium includes microorganisms that are very small and not visible to the eye. In addition, this bacteria do not leave any odor or taste in food. Unless the food contains large amounts of Salmonella $s p$, it would changes the color and odor (pale pink to greenish, foul smelling). The existence of Salmonella $s p$ must be negative in the food standard. According to Brooks (1996) that Salmonella is often pathogenic to humans or animals when entered through the mouth. Infection by the genus Salmonella (therefore called Salmonellosis) attacks the gastrointestinal tract includes the stomach, small intestine, and large intestine or colon, which can cause enteritidis, cytonic infections and enteric fever. SNI (2009) The maximum limit of Salmonella sp microbial contamination in food is Negative / $25 \mathrm{~g}$.

Research conducted by Yuswananda (2015) showed 4 of 11 samples analyzed obtained contamination salmonella sp. They were sample 1 (tofu jeletot), sample 2 (batagor), sample 7 (kebab) and sample 11 (wet spring roll). Lasmini and Sitorus (2017) research results 1 of 4 samples of kebab's meat tested only 1 sample containing Salmonella sp. The kebab meat in the UMM region negatively contained Salmonella sp, so it could still be consumed. Meat microbes can be sourced from the meat originating affected by infection during raising livestock, before and after slaughtering. Microorganisms can damage meat originate from infection in live cattle 
and postmortem meat contamination. Pathogenic microorganisms obtained from poultry meat include Aeromonas sp., Campylobacter sp., Clostridium perfringens, Listeria, Salmonella, Shigella, Streptococcus, S. aureus, Yersinia enterocolitica, and E. coli (Hargis et al., 2001). The physical condition of the meat and environmental conditions also affect the growth of microorganisms. The relative humidity is too high, the liquid will condense on the surface of the meat so the surface of the meat becomes wet and it is very conducive to the growth of microorganisms. The relative humidity is too low, the surface fluid of the meat will evaporate so microbial growth is inhibited by dehydration and the surface of the meat becomes dark (Soeparno, 2009).

\section{CONCLUSION}

The study concludes that two out of four kebab outlets in the UMM area showed the bacteria total counts above of the contamination limit set by SNI 7388:2009 and all of kebab's meat were negative identified or did not contain E. coli, $S$. aureus and Salmonella.

\section{ACKNOWLEDGMENT}

We would like to thank Faculty of Agriculture and Animal Husbandry, University of Muhammadiyah Malang for granting Blockgrant Grants for this research.

\section{REFERENCES}

Adams, M., \& Motoarjemi, Y. (2013). Dasar-dasar Keamanan Makanan untuk Petugas Kesehatan. Jakarta: EGC.

Adejuwon, A. O., Ogunkanmbi, D., Fadeyi, B. O., \& Agboola, O. A. (2011). Staphylococcus aureus isolated from septic caesaerean wound at Ile Ife Nigeria: Antibiotics susceptibility patterns. International Journal of Medicine and Medical Sciences, 3(5), 149-154.

Badan Pengawas Obat Dan Makanan. (2008). Pengujian Mikrobiologi Pangan. In Info POM (2nd ed.). Jakarta.

Betty, \& Yendri. (2007). Cemaran Mikroba Terhadap Telur Dan Daging Ayam. Padang: Dinas Peternakan Provinsi Sumatera Barat.

Brooks, F. G. (1996). Mikrobiologi Kedokteran. Jakarta: Penerbit Buku Kedokteran EGC.

Choiriyah, S. N., Hestiningsih, R., \& Yuliawati, S. (2016). Gambaran jumlah kuman total pada sampel daging kebab stand di kota Semarang. Jurnal Kesehatan Masyarakat (eJournal), 4(4), 460-464.

Chotiah, S. (2009). Cemaran Staphylococcus aureus Pada Daging Ayam dan Olahannya. In Balai Besar Penelitian Veteriner (pp. 682-687). Seminar Nasional Teknologi Peternakan dan Veteriner.

Fardiaz, S. (1993). Analisis Mikrobiologi Pangan. Jakarta: Raja Grafindo Persada.

Gwyneth, B. (2009). The Composistion and Labeling of Doner Kebab. LACORS. Coordinated Food Standards Survey.

Hargis, B. M., Caldwell, D. J., \& Bird, J. A. (2001). Microbiological Pathogen: Live Poultry Consideration. In A. R. Sams (Ed.), Poultry Meat Processing. New York: CRC Press. 
Kayisoglu, S., Yilmaz, I., Demirci, M., \& Yetim, H. (2003). Chemical composition and microbiological quality of the doner kebabs sold in Tekirdag market. Food Control, 14(7), 469-474. https://doi.org/10.1016/S09 56-7135(02)00103-2

Lasmini, T., \& Sitorus, R. Y. (2017). Uji cemaran Salmonella sp dan Staphylococcus aureus pada daging kebab yang dijual di jalan durian Pekanbaru. Jurnal Sains Dan Teknologi Laboratorium Medik, 2(1), 23-30.

Lversluys. (2015). History of the Kebab.

Novianti, D. (2015). Pemeriksaan kandungan bakteri Escherichia coli pada jajanan bakso tusuk di Pasar Tradisional Kota Palembang. Sainmatika: Jurnal Ilmiah Matematika Dan Ilmu Pengetahuan Alam, 12(2). https://doi.org/10.31851 /SAINMATIKA.V12I2.956

Soeparno. (2009). Ilmu dan Teknologi Daging. Yogyakarta: Gadjah Mada University Press.
Standar Nasional Indonesia. (2009). Metode Pengujian Cemaran Mikroba Dalam Daging, Telur Dan Susu, Serta Hasil Olahannya. Jakarta.

Sugiyoto, Adhianto, K., \& Wanniatie, V. (2015). Kandungan mikroba pada daging sapi dari beberapa pasar tradisional di Bandar Lampung. Jurnal Ilmiah Peternakan Terpadu, 3(2), 27-30. https://doi.org/10.23960 /JIPT.V3I2.P\%P

Syukur, D. (2006). Biosecurity terhadap Cemaran Mikroba dalam Menjaga Keamanan Pangan Asal Hewan. Bandar Lampung: Dinas Peternakan dan Kesehatan Hewan Provinsi Lampung.

Wulandari, E., \& Zubaidah, E. (2015). Kebab bakso bakar: inovasi kuliner khas kota Malang menjadi modern sebagai upaya pelestarian kuliner bangsa. Jurnal Pangan Dan Agroindustri, 4(1), 230-237.

Yuswananda, N. (2015). Identifikasi Bakteri salmonella sp pada Makanan Jajanan di Masjid Fathullah Ciputat Tahun 2015. Universitas Islam Negeri Syarif Hidayatullah, Jakarta. 